\title{
Investigation and Research on the present situation of geography education practice course in Colleges and Universities Xia Liu
}

\author{
Pingxiang University, Jiangxi 337055, China
}

\begin{abstract}
Key words: colleges and universities; geography education; practice course; current situation
\end{abstract} investigation

\begin{abstract}
Colleges and universities is to cultivate qualified middle school geography teaching practice courses in the full-time teacher, should pay attention to improve the teaching ability of the students, construction of education professional education practice reasonable curriculum system reform of education, professional education practice curriculum content, to make the educated geography students can adapt to the need of the basic education reform.
\end{abstract}

\section{Question put forward}

The geography education college students in participating in the process of education practice, whether their teaching ability can meet the needs of teaching? They go to work, whether the teaching competence of teaching needs? Most people would think that there should be no problem, but in fact it is not the case, the teaching practice ability has great deviation.

One of the core objectives of cultivating geography education in Higher Professional Colleges and universities is geography teaching ability, but the study of Geography in professional education, first, existing research limitations, the research focus on the students' basic skills on the map. Second, the current research on the geography of the practice of teaching in the empirical analysis of the status quo, we investigate the current situation of geography education students in the practice process of education practice. The results show that geography education undergraduate training in higher normal universities can basically meet the needs of basic education reform, but there are certain problems, we expect this study to further improve the geography education specialty in normal universities teaching ability training theory and practice to provide a reference.

\section{Research object and research method}

\subsection{Research object}

In order to fully do the research, 90 professional geography education object in the survey from a normal university intern, conducted a questionnaire survey to them, to understand the students' individual evaluation of self teaching ability.

\subsection{Research methods}

2.2.1 Literature data method: access to relevant literature and information

2.2.2 Expert interview method: through interviews with relevant experts, it is mainly to make clear the factors that affect the geography teaching ability of geography education majors.

2.2.3 Questionnaire survey method: 90 students of geography education were conducted a questionnaire survey, mainly survey the cognitive ability of geography teaching, geography teaching design ability, geography teaching operation ability and geography teaching management ability. 


\section{The present situation of geography education practice course}

\subsection{The evaluation of the teaching ability of the middle school geography teachers to the students}

College Students' teaching ability, mainly reflected in the geography classroom teaching practice, practice base of middle school geography teacher performance evaluation of college students in teaching in the process of education practice ability, can well reflect the basic situation of students' teaching ability.

3.1.1 Geography teaching cognitive ability. Mainly refers to the geography teachers based on the geography curriculum standard, the teaching goal of geography curriculum, geography curriculum teaching task understanding, teaching methods and strategies according to the actual situation of the students of the specific content of the relevant geography teaching is adopted, and the actual situation of geography teaching judgment and analysis. Research shows that in three, the elements of geography teaching cognitive ability, ability of student analysis of physical geography curriculum standards. Strong students accounted for 31\%, capable of handling application of geography textbooks accounted for 54\%, accounted for $23 \%$ of the student's ability of psychological characteristics and judgment about the teaching object, to be sure the geographical processing ability of interns in the textbooks in the analysis, the ability to understand the geography curriculum standards in general, and on the psychological characteristics of students understanding and judgment ability is relatively weak.

3.1.2. In the analysis and understanding of geography teaching design of geography curriculum standards, teachers based on geography classroom teaching goals, heavy and difficult content, teaching methods and teaching ability of the main elements of doing scientific and detailed teaching plan. The survey shows that in the five elements of geography teaching design, the students have a good teaching focus the ability to grasp the difficulty, ability to design the teaching process, the ability of the proportion of students accounted for $38 \%$ and $41 \%$, and make students in the teaching objectives, the design of sub elements selection and teaching methods of teaching problems worse, ability of students accounted for $27 \%$, 29\% and 34\%.

3.1.3 Geography teaching skills. As the occupation requirements, teachers have the ability to solve practical problems in teaching for geography teaching skills, can well show the art of teaching, classroom teaching is the guarantee of efficient. Its capacity is mainly reflected in the geography teachers' speech skills, blackboard writing, geographic board pictures, geographical teaching demonstration ability, the operation ability of geography experiment, using geography multimedia technology ability.

3.1.4 Geography teaching management. In order to achieve efficient geography teaching purpose, teaching ability as the most advanced components in the composition, the whole process management ability of geography teachers teaching activities mainly embodies the following three contents: one is the reflection of teaching ability of geography; two is the evaluation of the ability to teach geography; three is the geography teaching research ability. Intern in this capacity is obviously insufficient, the rates were $21 \%, 19 \%, 16 \%$.

\subsection{The evaluation of students' self teaching ability in geography education}

Students' evaluation of their geography teaching ability is an important dimension to understand students' geography teaching practice ability, and can understand the situation of geography teaching practice ability through the self evaluation of teaching ability.

3.2.1 Geography teaching cognitive ability. In the survey, the three elements of self cognitive ability in intern analysis to understand the geography curriculum standard level of good student proportion of $28 \%$, ability to deal with the application of geography textbook for $45 \%$, understanding and judgment on students' personality characteristics accounted for 33\%, the geographical processing ability of interns in teaching materials. Understanding and judgment on the student's personality, and ability to understand the analysis of geography curriculum standard is poor. This practice and teachers of students geography teaching cognitive ability evaluation of a slight deviation. 
3.2.2 The design of geography teaching. The study shows that in the five elements of geography teaching design, the students have a good teaching focus, difficult to grasp the strong ability, strong ability and strong students accounted for $79 \%$, the ability to design the teaching process, strong ability and strong accounted for $64 \%$ of students, and students in the formulation of teaching objectives, teaching methods selection and teaching problems of the design elements such as poor ability of students accounted for $31 \%, 32 \%$ and $37 \%$. From the point of view of the evaluation of teaching design ability, the self evaluation of geography education students is higher than that of the teachers.

3.2.3 Geography teaching skills. According to the survey results can be seen that the students with better ability in teaching and operation method, the expression of intern language in geography teaching ability of the students accounted for $73 \%$, accounting for $55 \%$ of the presentation aids ability, using multimedia 52\% strong, writing ability accounted for 53\%, in the plate pictures ability strong intern accounted for 39\%, the experimental operation ability of students accounted for only $25 \%$, at a general level, but from the overall, interns performed better in teaching operation and teaching means; from operating activities, students present ability in teaching, especially the classroom teaching organization ability is poor, Its ability is strong students accounted for $23 \%$ and $17 \%$ respectively. This shows that the interns in the teaching will focus on the main focus of the teaching, and can not allocate energy to carry out a good organization of teaching.

3.2.4 Geography teaching management capabilities. Three kinds of elements in the geography teaching management ability, ability to reflect the intern geography teaching geography teaching evaluation ability accounted for $24 \%$, accounting for $23 \%$, indicating that the $19 \%$. This shows that the students' ability of teaching management is poor.

\section{The problems in the cultivation of the teaching practice ability of the geography education major}

\subsection{The curriculum system is not reasonable}

At present, the professional course of geography education in normal colleges and universities set up professional curriculum system needs to be adjusted, following problems: first, more emphasis on professional attribute of geography; second, ignore setting education and teaching curriculum, especially the integration of teaching theory and teaching practice, the teaching of the curriculum, training the application is not conducive to the students the basic knowledge of teaching theory and practical teaching ability.

\subsection{The teaching practice is not sufficient}

The formation of the geography teaching practice ability cannot do without the teaching practice process, but the course of geography education in Colleges and universities of professional settings are more theoretical courses, the lack of practical teaching ability of geography education curriculum independent and comprehensive, this is not conducive to understanding for students master geography teaching theory, especially the application of student teaching theory into teaching ability in the teaching practice, the lack of skills training is a common problem to set the current geography education curriculum.

\subsection{The lack of teaching practice ability evaluation mechanism}

Teaching evaluation is based on certain teaching objectives and standards of teachers and students for detection and assessment of its value and the advantages and disadvantages in order to improve the process, it is the basis for all successful teaching, to guide the teaching of teachers, has a great theoretical and practical significance to improve the teaching quality through. Evaluate the practice ability of education and teaching system to help students and teachers a clear standard, in order to find deficiencies. Lack of evaluation system of Geography Education Specialty in normal universities students' abilities in teaching practice, the students and teachers are not able to grasp and understand the teaching ability of the current situation and existing problems of objective evaluation is not teaching ability the education of students, is not conducive to the formation and development of the teaching ability of geography education majors. 


\section{Improve the teaching practice ability of geography education in Normal Universities}

\subsection{The construction of a reasonable curriculum system of educational practice}

Geography science education curriculum system is an important factor causing unreasonable teaching ability of students majoring in geography education and teachers' occupation quality is not high. For a long time, geography professional course occupies a great proportion of the education curriculum, the proportion is very small, only a long time education, psychology, geography teaching method, teaching practice curriculum, activity in a very small proportion of internship and practice. Only a few weeks of elective courses with little or no related educational courses and geography education courses, compared with the world advanced level, curriculum imbalance, course construction is backward. Therefore, it is extremely urgent to reform the curriculum setting of the geography teacher education, and to accelerate the development and construction of the education curriculum.

\subsection{Reform of educational practice curriculum content}

High quality education teaching content is an important factor to ensure the quality of teaching, geography education majors education so that to solve the problem of geography education teaching professional students, improve the quality of training, but also the transformation of traditional education, the old teaching content. The theoretical level of high education teaching contents on the one hand, pay attention to learning and reference research the results of similar courses abroad, geography teaching theory. On the other hand, to strengthen the teaching practice of theory and application, can be increased in the course of case analysis, strengthen the geography teaching skills training.

\section{Reference}

[1] Li-min Yao. Research on [J]. effect of higher education teacher factors of effective teaching $(2004,1)$

[2] Zi-qi Liu. Geography teaching in universities should strengthen the research on the new curriculum of students' map literacy training [J]., 2010, (2)

[3] Shao Wang.The multidimensional structure of College Teachers' teaching ability [J]. Journal of Shenyang Normal University: Social Science Edition, 2010, (1) 